\title{
Hedgehog-Interacting Protein
}

National Cancer Institute

\section{Source}

National Cancer Institute. Hedgehog-Interacting Protein. NCI Thesaurus. Code 127011.

Hedgehog-interacting protein (700 aa, $\sim 79 \mathrm{kDa}$ ) is encoded by the human HHIP gene.

This protein plays a role in the regulation of hedgehog signaling pathways. 